\title{
한국재래닥 $\mathrm{COI}$ 유전자의 단일염기다형 분석
}

\author{
진선덕 ${ }^{1} \cdot$ 서동원 $^{2} \cdot$ 심정미 ${ }^{2} \cdot$ 백운기 $^{1} \cdot$ 정기철 ${ }^{2} \cdot$ 장병귀 $^{3} \cdot$ 최강덕 $^{4} \cdot$ 이준헌, ${ }^{2}{ }^{\dagger}$ \\ ${ }^{1}$ 국립중앙과학관, ${ }^{2}$ 충남대학교 동물자원과학부, ${ }^{3}$ 농촌진흥청 난지농업연구소, ${ }^{4}$ 한경대학교 생물정보통신대학원
}

\section{Single Nucleotide Polymorphism Analysis of the COI Gene in Korean Native Chicken}

\author{
S. D. Jin ${ }^{1}$, D. W. Seo ${ }^{2}$ J. M. Sim², W. K. Baek ${ }^{1}$, K. C. Jung' ${ }^{2}$, B. K. Jang ${ }^{3}$, K. D. Choi ${ }^{4}$ and J. H. Lee ${ }^{2,}$ \\ ${ }^{I}$ National Science Museum, ${ }^{2}$ Division of Animal Science and Resources, Chungnam National University \\ ${ }^{3}$ National Institute of Animal Science, R.D.A., ${ }^{4}$ The Graduate School of Bio \& Information Technology, Hankyong National University
}

\begin{abstract}
One of the mitochondrial genes, called cytochrome c oxidase I (COI), has been widely used for the species identification (called bio-barcode) in birds. In this study, the bio-barcode has been applied to chicken breeds in Korea whether it also can be used as a molecular marker for breed identification. Data indicated that Korean native chicken has the mixed SNP (single nucleotide polymorphism) patterns between White Leghorn (Layer) and Cornish (Broiler) and ultimately, it can not be used as the marker for breed identification. However, this result indicates the mixed use of the Korean native chicken, since it has been used for dual purpose for producing meat and egg for a long time. In order to use as a marker for species identification, more reliable mitochondrial and/or nuclear DNA markers need to be developed.
\end{abstract}

(Key words : COI gene, mitochondria, Korean native chicken, breed identification)

\section{서 론}

현존하는 닭의 조상은 일반적으로 여러 품종이 합쳐서 형 성이 되었다는 다원설과 적색야계(Gallus gallus)가 현존하는 닭의 기원이라는 단원설이 제기되고 있다(Crawford, 1990). 종간, 품종간 연관 관계를 확인하기 위하여 미토콘드리아 $\mathrm{DNA}(\mathrm{mtDNA})$ 변이가 많이 사용되고 있는데, 이 미토콘드리 아 DNA는 genomic DNA와는 달리 원형이며 모계유전을 하 는 특성이 있고 recombination이 일어나지 않는다는 특징을 가지고 있다. 이런 특성 때문에 미토콘드리아 DNA는 종간, 품종간 계통 분석에 많이 이용되며, 특히 mtDNA중 가장 변 이가 많다고 알려진 D-loop내 변이를 이용하여 닭의 품종간 연관 관계를 구명한 논문이 많이 발표되었다(Niu 등, 2002; Liu 등, 2004; Liu 등, 2006). 이 미토콘드리아 D-loop 변이는 조류뿐 아니라 포유동물의 계통유전학적 분석에 많이 이용 되고 있다. 최근 미토콘드리아내에 존재하는 cytochrome c oxidase I(COI) 유전자의 변이를 이용하여 종의 구별 마커로 이용하려는 시도가 계속되고 있다(Hebert 등, 2003). 특히 조
류에서는 그 결과가 괄목할 만하여 Hebert 등(2004)은 북미 조류 667종 중 260종을 COI 유전자를 통해 분류하였고, Yoo 등(2006)은 국내 서식하는 조류 450종 중 92종을 COI 유전자 를 통해 분류하였다. COI sequence의 분류 결과로 대부분의 목, 과, 속은 현존 분류학과 일치하는 이중 단계원적 계보 (nested monophyletic lineages)와 같이 나타나 높은 수준의 조 류 분류가 대체로 일치하는 경향을 보였으며, 기존에 보고되 지 않은 새로운 종도 발견할 수 있는 계기를 마련해 주고 있 다(Hebert 등, 2004).

타 종에서 품종을 구분하기 위한 DNA 마커의 개발은 최 근 소에서 그 예를 들을 수 있으며, 소의 품종 구분 DNA 마 커로 SRY, ND4, ND5가 보고되었으며, 이중 ND4와 ND5는 미토콘드리아 내에 존재하는 유전자로 Bos indicus와 Bos taurus를 분류하는데 아주 유용한 마커로 사용되고 있다(Yoon 등, 2008). 이런 결과를 통하여 볼 때 품종을 구분하기 위한 유용한 마커는 미토콘드리아 내에 존재할 가능성이 매우 높 다.

닭은 인류에게 닭고기와 계란을 통하여 손쉽게 단백질을

† To whom correspondence should be addressed : junheon@cnu.ac.kr 
공급해 주는 동물로서 2004년 genome sequencing의 초안이 발표된 이후 그 중요성이 인정되어 발생학, 면역학, 비교 생 물학의 연구에 중요한 모델 동물로 인식되고 있다(Wallis 등, 2004). 세계에는 약 120 여 닭 품종이 보고되고 있으며, 이들 품종은 적게 쓰이는 품종부터 점차 멸종되어가고 있는 실정 이다(http://www.poultrypages.com/chicken-breeds.html). 닭의 품 종을 보존하려는 움직임이 최근에 일고 있으며, 한국에서는 1980년대부터 재래닭을 보존하려는 연구가 시작되어 현재 결 실을 맺고 있다. 또한, 최근 국민소득의 증가로 육질이 좋고 지방이 적은 재래닭을 선호하는 소비층이 증가하고 있다(오 등, 2005). 한국 재래닭의 상업화를 위하여 한국 재래닭 특이 마커의 개발이 절실히 필요하다. 따라서 본 연구는 한국 재 래닭의 품종 특이 마커의 탐색을 위하여 조류에서 종판별 마커로 사용되고 있는 $\mathrm{COI}$ 유전자의 변이를 산란계인 White Leghorn, 육계인 Cornish와 비교함으로써 차후 품종구분 유 전적 표지로서의 가능성을 제시하고자 실시하였다.

\section{재료 및 방법}

\section{1. 공시 재료}

본 연구에 이용된 공시재료는 축산과학원(성환) 가금과에 서 보유한 한국재래계 3수와 Cornish 3수, 백색 레그혼(White Leghorn) 7 수를 이용하였다.

\section{DNA 추출}

공시계의 익정맥에서 $200 \mu \mathrm{L}$ 의 혈액을 EDTA가 함유된 tube에 채혈하였으며, DNA 추출은 PrimePrep ${ }^{\mathrm{TM}}$ Genomic DNA Isolation Kit(Genetbio, Korea)와 MagExtractor ${ }^{\circledR}$ Genome kit(Toyobo, Japan)를 이용하여 지침서에 따라 추출하였고, 추출된 DNA는 실험에 이용될 때까지 $4{ }^{\circ}$ 에 저장하였다.

\section{3. $\mathrm{COI}$ 유전자의 $\mathrm{PCR}$ 증폭 및 정제}

닭 mitochondria DNA에 존재하는 $\mathrm{COI}$ 유전자의 일부분을 증폭하기 위한 primer는 Dawnay 등(2007)에 의해 보고된 primer들 중 Gallus gallus 특이 primer(Forward primer: 5' TCT CAA CCA ACC ACA AAG ACA TTG G 3', Reverse primer: 5' TAA ACT TCG GGG TGA CCG AAG AAT CA 3')를 이 용하였다. PCR(Polymerase Chain Reaction) 증폭은 앞서 추출 한 genomic DNA에 10X 반응 완충액(Tris-HCl pH 9.0, $200 \mathrm{mM}$ $\mathrm{MgCl}_{2},\left(\mathrm{NH}_{4}\right)_{2} \mathrm{SO}_{4}, \mathrm{PCR}$ enhancers), $10 \mathrm{mM} \mathrm{dNTP}$, forward와 reverse primer 각각 10 pmol, 1.5 units Taq DNA polymerase
(Genetbio, Korea)와 genomic DNA 그리고 멸균수를 첨가하 여 총 $20 \mu \mathrm{L}$ 용량으로 반응하였다. $\mathrm{PCR}$ 반응 조건은 최초 denaturation으로 $95{ }^{\circ} \mathrm{C}$ 에서 5 분간 반응시킨 후, $95{ }^{\circ} \mathrm{C}$ 에서 30 초, $60{ }^{\circ} \mathrm{C}$ 에서 30 초, $72{ }^{\circ} \mathrm{C}$ 에서 30 초에서 35 회 반복하였으며, $72{ }^{\circ} \mathrm{C}$ 에서 7분간 final extension후 $4{ }^{\circ} \mathrm{C}$ 에서 종료하였다. $\mathrm{PCR}$ 증폭산물은 PCR Purification Kit (Bioneer, Korea)을 사용하여 정제하였다.

\section{4. 유전자 염기서열 분석}

각 품종별 닭 $\mathrm{COI}$ 유전자 염기서열을 확인하기 위하여 sequencing을 실시하였다. 염기서열 분석은 정제된 PCR 증 폭 산물을 Geno Tech(Korea)에 의뢰하여 direct sequencing 방 법으로 실시하였으며, Chromas software(Technelysium, Australia)를 사용하여 염기서열을 확인하였다. 확인된 염기서열은 ClustalW program을 이용하여 alignment한 후 단일염기다형 을 확인하였다(http://www.ebi.ac.uk/Tools/clustalw2). Sequence divergency는 Kimura2 parameter(K2P)모델을 이용하여 계산 하였고, 계통도 분석은 MEGA3 프로그램(Kumar 등, 2004)을 이용하여 K2P를 이용한 Neighbor-Joining(NJ) 방법으로 수행 하였다.

\section{결과 및 고찰}

$\mathrm{COI}$ 유전자는 동물의 종을 구별하는 유용한 marker로 이 용되고 있다. 특히 조류에서 이 유전자의 변이를 종의 구분 에 이용하여 괄목할만한 성과를 나타내고 있다(Hebert 등, 2004; Yoo 등, 2006). 이 유전자의 변이를 이용하여 닭의 품 종 구분이 가능한지를 확인하기 위하여 한국 재래계 3 수, Cornish 3수, White Leghorn 7수의 mtDNA COI region을 PCR 증 폭한 후 sequencing하여 모든 품종에서 $680 \mathrm{bp}$ 의 염기서열을 관찰하였다. 이들 sequence를 align하여 분석한 결과 총 2 개 의 haplotype으로 분리되었으며, 3 개의 단일염기다형(SNP)을 확인할 수 있었다(Fig. 1). 염기서열 분석 결과 한국 재래닭은 공시축으로 사용한 산란계인 White Leghorn과 육계인 Cornish가 가지고 있는 SNP를 모두 가지고 있는 것으로 판명되 었다(Fig. 1). 또한, NJ(Neighbor- joining) tree에서 White Leghorn 종(haplotype 1)과 Cornish 종(haplotype 2)이 산란계와 육용계의 형태로 확연히 분리되는 것을 확인할 수 있었다 (Fig. 2). 그러나 White Leghorn 7의 경우는 산란계이지만 육 용계와 같이 집단을 형성하고 있어 White Leghorn 7의 경우 표현형적으로는 산란계이지만 Mitochondria는 육계의 형태를 


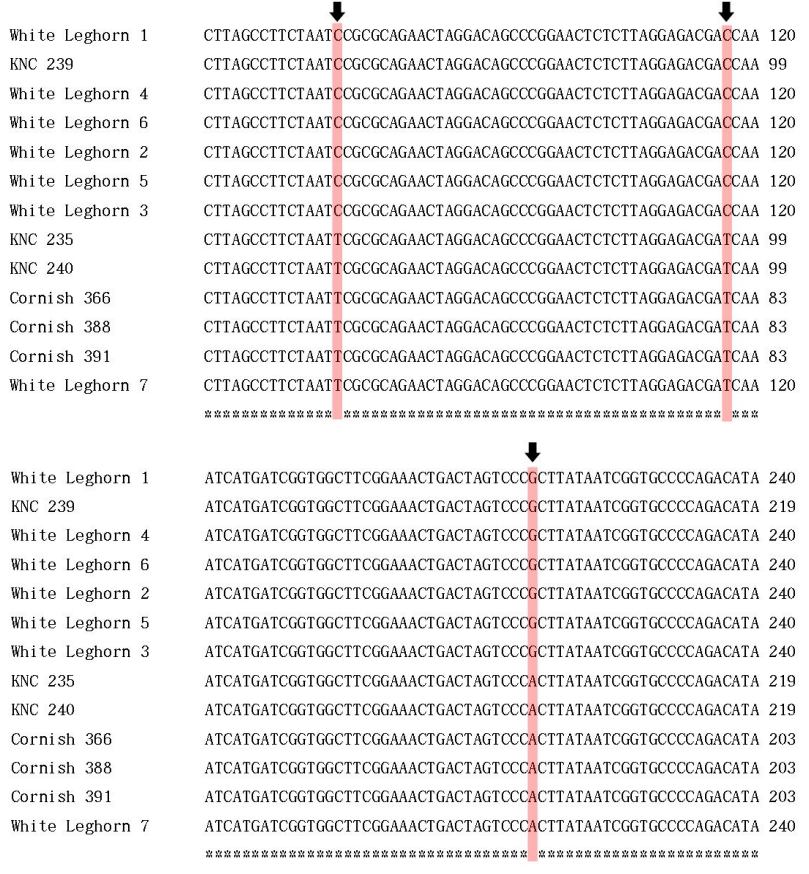

Fig. 1. Comparison of the COI sequence among KNC (Korean native chicken), Cornish and White Leghorn breeds. Arrows indicate identified SNPs in this study.

아직도 가지고 있는 것으로 추정할 수 있다. 이 연구 결과를 입증하기 위해서는 더 많은 연구가 필요할 것으로 사료된다. 본 연구 결과를 종합하여 볼 때 $\mathrm{COI}$ 유전자는 한국재래닭의 품종을 구분하기 위한 품종 구분 마커로 사용하기에는 적합 하지 않은 것으로 확인되었다. $\mathrm{COI}$ 유전자는 종 수준에서 분류가 가능한 유전자로 본 연구의 결과에서 haplotype 1과 2 의 유전적 차이는 $0.4 \%$ 로 다른 연구 결과의 종간 유전적 차 이 $0.3 \%$ 로 보다 높아 본 결과는 종 수준으로 분류된 것으로 나타났다(Yoo 등, 2006). 본 연구 결과를 통하여 한국 재래계 가 육계와 산란계의 특성을 모두 가지고 있는 난육 겸용이 라는 기존의 학설을 뒷받침하였으며, 가금은 사용 목적에 맞 는 육종을 통하여 다른 특성을 가진 품종으로 개량될 수 있 음을 나타내 주기도 한다.

본 연구를 통하여 재래닭, White Leghorn, Cornish의 염기 서열을 바탕으로 다른 근연종과의 연관 관계를 알아보기 위 해 NCBI에서 Gallus gallus spadiceus(Accession No. AP003321), G. g. bankiva (Accession No. AP003323), G. g. gallus(Accession No. AP003322), Gallus sonneratii(Accession No. AP006741), G. varius(Accession No. AP003324), G. lafayettiei(Accession No. AP003325) 6종의 염기서열을 확보한 후 이를 비교 분석 하였다. 그 결과 각각의 분류군은 종간에 차이를 보여 4 개의

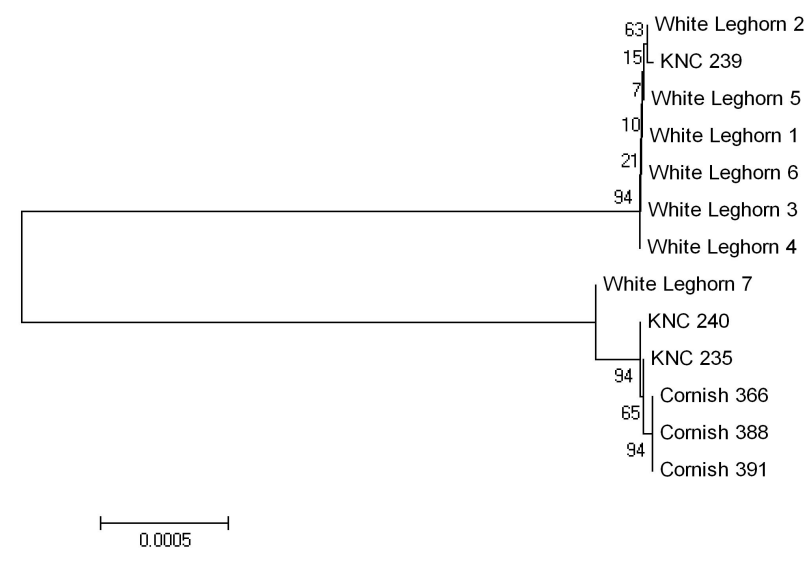

Fig. 2. Phylogenetic tree among KNC (Korean native chicken), Cornish and White Leghorn breeds.

그룹으로 크게 나누어짐을 알 수 있었다. 적색야계(Red jungle fowl)에서 분화된 것으로 알려진 Gallus gallus spadiceus, G. g. bankiva 그리고 G. g. gallus는 재래닭과 Cornish와 동일 group 내에서 나타났고, White Leghorn종은 회색야계(Gray jungle fowl)와 동일한 group에 존재함을 확인할 수 있었다. 또한 Gallus varius와 Gallus lafayettiei는 각각 독립적인 group 을 형성하고 있음을 확인할 수 있었다.

본 연구를 통하여 $\mathrm{COI}$ 유전자의 변이가 닭의 품종을 구분 하는데 어려움이 있었지만 기존 연구에서와 같이 품종간의 분류를 할 수 있는 다른 marker를 개발한다면 보다 정확한 가금류의 품종 분류가 가능할 것으로 판단되며, 앞으로 이 분야의 연구가 더 활성화되어야 한다고 생각한다. 궁극적으 로 이런 $\mathrm{DNA}$ 마커의 확보를 통해 품종 보존, 육종 전략을 수립하는데 매우 중요하게 이용될 것으로 사료되며, 품종 구 분을 위하여 미토콘드리아와 genomic DNA 유래 단일염기다 형 확보의 중요성을 재확인할 수 있었다.

\section{적 요}

조류에서 미토콘드리아내 유전자인 cytochrome c oxidase $\mathrm{I}(\mathrm{COI})$ 는 종 구분을 위한 바이오마커로 많이 이용이 되고 있 다. 본 연구는 이 유전자의 변이를 이용하여 닭의 품종 구분 이 가능한지를 실험하기 위하여 실시하였다. 그 결과 한국 재래닭은 공시축으로 사용한 산란계인 White Leghorn과 육 계인 Cornish가 가지고 있는 단일염기다형을 모두 가지고 있 는 것으로 판명되어 품종구분을 위한 마커로 사용하기에는 적합하지 않은 것으로 확인되었다. 그러나 본 연구 결과를 
통하여 한국재래계가 육계와 산란계의 특성을 모두 가지고 있다는 기존의 학설을 뒷받침하였으며, 품종 구분을 위하여 미토콘드리아와 genomic DNA 유래 단일염기다형 선발의 중 요성을 확인할 수 있었다.

\section{사 사}

본 연구는 농촌진흥청의 FTA 대응기술개발사업(실용계 토종닭의 품종 식별 및 집단유전학적 분석)의 지원에 의해 수행되었습니다.

\section{인용문헌}

Crawford RD 1990 Origin and history of poultry species. In: Poultry Breeding and Genetics (Ed. R. D. Crawford) Elsevier. pp7-8.

Dawnay N, Ogden R, McEwing R, Carvalho GR, Thorpe RS 2007 Validation of the barcoding gene COI for use in forensic genetic species identification. Forensic Sci Int 173(1): $1-6$.

Hebert PDN, Cywinska A, Ball SL, DeWaard JR 2003 Biological identifications through DNA barcodes. Proc R Soc Lond B Biol Sci 270:313-321.

Hebert PDN, Stoeckle MY, Zemlak TS, Francis CM 2004 Identification of birds through DNA barcodes. PLoS Biol 2: e312.

Kumar S, Tamura K, Nei M 2004 MEGA 3.1: Integrated software for molecular evolutionary genetics analysis and sequence alignment. Brief Bioinformatics 5:150-163.

Liu YP, Wu GS, Yao YG, Miao YW, Luikart G, Baig M, Pe- reira AB, Ding ZL, Palanichamy MG, Zhang YP 2006 Multiple maternal origins of chickens: Out of the Asian jungles. Mol Phylogenet Evol 38(1):12-19.

Liu ZG, Lei CZ, Luo J, Ding C, Chen GH, Chang H, Wang KH, Liu XX, Zhang XY, Xiao XJ, Wu SL 2004 Genetic variability of mtDNA sequences in Chinese native chicken breeds. Asian-Aust J Anim Sci 17(7):903-909.

Niu D, Fu Y, Luo J, Ruan H, Yu XP, Chen G, Zhang YP 2002 The origin and genetic diversity of Chinese native chicken breeds. Biochem Genet 40:163-174.

Wallis JW, Aerts J, Groenen MA, Crooijmans RP, Layman D, Graves TA, Scheer DE, Kremitzki C, Fedele MJ, Mudd NK, Cardenas M, Higginbotham J, Carter J, McGrane R, Gaige T, Mead K, Walker J, Albracht D, Davito J, Yang SP, Leong S, Chinwalla A, Sekhon M, Wylie K, Dodgson J, Romanov MN, Cheng H, de Jong PJ, Osoegawa K, Nefedov M, Zhang H, McPherson JD, Krzywinski M, Schein J, Hillier L, Mardis ER, Wilson RK, Warren WC 2004 A physical map of the chicken genome. Nature 432(7018):761-764.

Yoo HS, Eah JY, Kim JS, Kim YJ, Min MS, Paek WK, Lee H, Kim CB 2006 DNA barcoding Korean birds. Mol Cells 22(3):323-327.

Yoon D, Kwon YS, Lee KY, Jung WY, Sasazaki S, Mannen H, Jeon JT, Lee JH 2008 Discrimination of Korean cattle (Hanwoo) using DNA markers derived from SNPs in bovine mitochondrial and SRY genes. Asian-Aust J Anim Sci 21(1): 25-28.

오재돈 박미현 공홍식 이학교 전광주 연성흠 상병돈 최철환 조병욱 2005 한국 재래 닭 품종 특성 및 초기성장 개량을 위한 분자표지 개발. 한국가금학회지 32(1): 29-34. (접수: 2009. 3. 2, 수정: 2009. 3. 28, 채택: 2009. 3. 29) 